\title{
Luottamuksen jäljillä
}

Samalla kun Suomessa on kesän alussa päästy koronaviruspandemian heikennyttyä vähentämään kokoontumisiin ja tapahtumiin liittyviä rajoituksia, rajan takana Venäjällä koronaan sairastuvuus on pysynyt korkeana ja lähtenyt jälleen kasvuun. Silti Venäjällä vasta noin 13 prosenttia kansasta on tätä kirjoittaessa ottanut rokotteen tautia vastaan, Suomessa ollaan jo noin 50 prosentissa.

Vähäistä innostusta rokotteisiin on pohdittu eri tahoilla. Yhtenä syynä matalaan rokotekattavuuteen voi olla ajatus siitä, ettei tauti ole vaarallinen itselle. Kesäkuun alussa julkaistu Levada-keskuksen mielipidemittaus kertoi, että yli puolet kansasta (55\% vastaajista) ei pelkää koronaan sairastumista; reilu $40 \%$ sen sijaan pelkää. Vastaajista neljännes kertoi jo sairastaneensa taudin, heistä suurin osa kylläkin ilman virallista diagnoosia.

Rokotustahdin hitauden yhteydessä on tuotu esiin myös yleinen epäluottamus viranomaisiin ja päättäjiin ja julkisuuteen kerrottuihin sairastapaus- ja kuolleisuuslukuihin. Levada-keskuksen toisessa kyselyssä toukokuussa selvisi, että vajaa neljännes vastaajista kertoo, ettei ole ketään poliitikkoa johon voisi luottaa. Tämä luottamuksen väheneminen on kasvanut parissa vuodessa merkittävästi. Maaliskuussa 2019 lukema oli vielä 17 prosenttia. Polarisoituneesta tilanteesta kertoo, että vastaajista noin puolet näkee, että maan tilanne yleisesti on hyvällä tolalla, mutta $40 \%$ on vastakkaista mieltä.

Gallupien tuloksetkin siis näyttävät, että tyytymättömyyttä ja luottamuksen puutetta on ilmassa. Tyytymättömyyden ilmaisemiselle on kuitenkin yhä rajatummin paikkoja, kun esimerkiksi riippumattoman median elintila on kutistunut. Uusimpia esimerkkejä on Latviassa pääpaikkaansa pitävän $M e d u z a$-verkkojulkaisun määrittäminen ulkomaiseksi agentiksi. Huhtikuussa tehty päätös määrää julkaisun esimerkiksi ilmoittamaan ulkomaisen agentin statuksesta jokaisessa yksittäisessä julkaisussa. Yksi merkittävimpiä seurauksia oli, että Meduza menetti kaikki mainostulonsa hetkessä ja joutui taloudellisiin vaikeuksiin - lukijoille suunnattu joukkorahoituskampanja on kuitenkin ainakin toistaiseksi pitänyt julkaisun pystyssä. Päätoimittaja Galina Timtšenkon mukaan uutislähteet eivät enää uskalla puhua lehdelle. Yhdysvaltalaisen Kennan-instituutin tilaisuudessa kesäkuussa Timtšenko kertoi, että statuksen muutos toi myös merkittäviä riskejä Meduzan journalisteille: on mahdollista että yksittäisiä henkilöitäkin lisätään ulkomaisten agenttien listalle, mikä tuottaisi heille tarkat raportointivelvoitteet toiminnastaan ja uhan jäädä listalle pysyvästi.

Meduzan tapaus kertoo karua kieltä lehdistönvapauden yleisestä tilanteesta Venäjällä. Valtakunnallisten julkaisujen lisäksi maahan mahtuu paljon alue- ja paikallisjulkaisuja, joissa 
on näkyvissä toivoa tuottaviakin kehityskulkuja. Olga Dovbyshin artikkeli tässä Idäntutkimuksen numerossa käsittelee paikallisia sosiaalisen median keskusteluryhmiä, joista on tullut monissa venäläisissä kaupungeissa tärkeitä paikallisen tiedon foorumeita ja osallistumisen mahdollistajia.

Tässä vapaan teeman numerossamme käsitellään myös mm. rahapelien vientiä Venäjälle Virve Marionneaun ja Johanna Järvinen-Tassopouloksen artikkelissa ja Ukrainan kielitilannetta Johanna Viimarannan ja Olli-Matti Mikkolan kolumneissa.

Kesäisiä lukuhetkiä Idäntutkimuksen parissa!

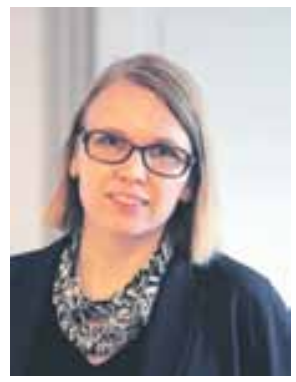

Katja Lehtisari 